\title{
INTER TAXATION OF UNIVERSITY STAFF SALARIES: THE ISSUE OF COLLECTIVE BARGAINING
}

\author{
Dr John Mark \\ Rivers State University, Port Harcourt, Faculty of Management Sciences, Department of Management
}

\begin{abstract}
The sudden slash of salaries of university staff in Rivers State has in recent times generated a threatening response against Rivers State Government. The argument remains that there was a violation of collective bargaining in the process of inter taxation. Second, there was no fixed ratio on which such measures were taken. Third, it contends with the spirit of service among staff. Against this backdrop then was the paper written. Objective of research was to find out if the petitions of staff were so. The paper was an empirical study on to interviews with 30 staffs from the two universities in the state. Inferred conclusion was that there was the violation of collective bargaining and state corporatism in the inter-taxation process.
\end{abstract}

Key words: inter-taxation; collective-bargaining

DOI: $10.7176 / \mathrm{EJBM} / 11-7-12$

Publication date:March $31^{\text {st }} 2019$

\section{INTRODUCTION}

In the classical economy not very many regards were accrued to workers. There was this imbalance of labour between management and employees as machines were seen to be more gainful than humans. The consequence was that workers were circumspect about their petitions and their discharge of duty in order not to lose their job. Ewekpum (2010)

But then, as workers became more enlightened about their rights, conditions of labour changed as there was now the emergence of system of work and harmonious relationship between management and workers. What we see as the brain child of this movement was Beautrice Webs' collective bargaining system. He defines collective bargaining as an economic condition where there is an inter service between supply and demands of labour. By this sense then, workers tender their services for sale and in return, the employer negotiates, following the principles of mutual respect for individual bargaining. Bernstein (1999).

In other words, the issue of supply and demand in organization setting is a thing of mutual respect. No one is to be seen as being more indispensable than the other; not even in the case of state interventionism or corporatism as we see between the Rivers State government and the university staff.

The issue of inter taxation of staff's salaries without the due process of collective bargaining was an abuse of power and disrespect for labour. This then reminds us of Flander's position. He defines collective bargaining as the process of labour interactism, whereby between supply and demands is the act of exchange.

As such the power relationship between employer and employees is to be measured on the scale of mutual respect and dialogue. The judicial precedence or quota or ratio is to be presented accordingly. Flander then argues that the issue of collective bargaining requires that of;

1. A means of contracting the service of labour

2. A firm of industrial legislature

3. A method of procedure from the management Flanders (1970)

It then follows that the paper proceeded with these three issues, arguing that the inter taxation of the staff's salaries did not follow due process of managerial theories.

\section{OBJECTIVES OF THE STUDY}

The purpose of the research was to

1. Ascertain the ratio at which the inter-taxation was carried out

2. To ascertain the effect of this on work performance of the university staff

3. To ascertain if there was any collective bargaining process before the action was carried out

\section{RESEARCH QUESTIONS}

The research then was guided with the following research questions:

1. At what ratio was the inter-taxation exercise carried out?

2. What effect did this have on work performance of staff? 
3. Was there any collective bargaining process before the exercise was carried out?

\section{SIGNIFICANCE OF RESEARCH}

With the emergence of collective bargaining, work performance between management and employees together with state corporatism, will further encourage and enhance a worthy work environment. In other words, based on standardization and best practices, collective bargaining restrains an enormous exercise of power and conflict in the industry. Absence of it paves way for impunity.

\section{STATEMENT OF PROBLEM}

Collective bargaining process in organization work performance provides industrial harmony. For one, with the emergence of trade unionism membership petitions have come to be heard. Besides, as workers get enlightened more in their rights and privileges in strict work conditions, terms of labour are basically on the rules of best practices. It then follows that in typical industrial harmony, collective bargaining is the rule of law. The management and employees are to sit on round table for dialogues. The essence of this is to shun conflict in the industry and further pave way for good work conditions as these are capable of affecting labour. Girigiri (2002).

In other words, the recent inter taxation exercise on university staff's salaries calls for questioning. To what extent was the state able to integrate into the exercise the spirit of corporatism? As well, what effect is this likely to have on the work performance of staff? Issues such as these ones, require the attention of scholars for the sake of tomorrow.

\section{CONCEPTUAL ISSUES OF COLLECTIVE BARGAINING}

In contemporary industrial practice, organizations are faced with uncertainties. These range from the issue of humans to inorganic factors. The degree of escalation of these forces from time to requires the training and creativity of industrial relations experts in checking such occurrences.

Of course, the most pronounced role of industrial relations experts is to manage conflicts and determine the conditions of service, especially between the management and her internal public. Sometimes too, it is between the management and her external publics. Dunlop (2009).

It then remains that the aptness of industrial relations outfits plays an enormous role in articulating the conditions of labour. In Egeonu (2015), the industrial relations experts is to negotiate and determine the conditions of service. Within this then, is the promotion of industrial harmony, packages, salary scales, good wages and reward system in order to efficiently facilitate industrial harmony and growth.

And then, in Akinyanju (1997) conflict doused through industrial harmony, reduces tensions and regulates power flaring within a given social structure.

In other words, the issue of conflict management has brought about a number of innovative steps for industries to follow, especially in Nigeria where human relations and resources are scarcely regarded. Instances as these require the interplay of industrial relations approach. Davies (1994).

One of such approaches is the use of collective bargaining, state interventionism and corporatism etc. Regarding the instrument of collective bargaining, wage determinants and work conditions are regulated. For one again, no other factor is capable of inducing industrial conflict other than these ones. Collective bargaining then is a measure for trade union disputes. It is an important instrument for state interference in moments of unrest between management and employees. In Egeonu (2015) as cited in Dunlop (2009). Collective bargaining is a machinery for industrial fellowship and negotiation between management and workers representatives with the aim of arriving at a mutual agreement against an emerging or a seated dispute in the industry.

It is also seen as a machinery for controlling the industrial relations market system, where upon it constitutes a platform for deliberating and deciding work conditions (Flander, 1965).

Collective bargaining in contemporary organization practice, then involves the auspices of the trade union on one hand and then the management. The government through, the instrument of judicial precedence, creates the environment in which such fellowships thrive. Practice thus comprising the government, the trade union and the management. In a strict model practice we have it as thus:

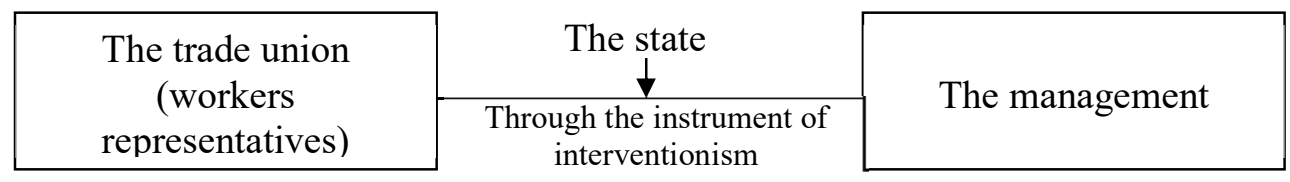

THE TRIPARTITE APPROACH OF COLLECTIVE BARGAINING 


\section{METHODOLOGY OF RESEARCH}

This study adopted the survey method of enquiry whereupon a sample of thirty scholars were interviewed from both schools, fifteen each from Rivers State University of Science and Technology and fifteen from Ignatius Ajuru University. Questionnaire was used as an instrument of data collection, following which Likert's scaling system was used to analyze the responses of the data collected from respondents.

To answer the three item questions, responses were in the order of:

1. Strongly agreed $-5(\mathrm{SA})$

2. Agreed - 4 (A)

3. Undecided $-3(\mathrm{U})$

4. Disagreed -2 (D)

5. Strongly disagree $-1(\mathrm{SD})$ total $=5+4+3+2+1=15 / 5=3.0$

\section{RESEARCH QUESTIONS}

At what ratio was the inter taxation exercise carried out?

Table 1: Ratio at which the exercise was carried out

\begin{tabular}{|l|l|c|c|c|c|c|c|c|}
\hline ITEM & & SA & A & U & D & SD & TOTAL & REMARK \\
\hline 1. & $\begin{array}{l}\text { There was likely no fixed ratio at which the } \\
\text { exercise was carried out; for those who earn } \\
\text { closely related salary were slashed without } \\
\text { a fixed ratio }\end{array}$ & 5 & 4 & 3 & 2 & 1 & 15 & 3 \\
\cline { 5 - 9 } & & 20 & 6 & 3 & 1 & - & 30 & 4.5 \\
\hline
\end{tabular}

From the above result we see the response of respondents at the mean value of 4.5. This implies there was no fixed ratio at which the exercise was carried out.

\section{Research Question 2}

What effect would the exercise have on staff's performance?

Table 2: The effect of this on staff's performance

\begin{tabular}{|l|l|c|c|c|c|c|c|c|}
\hline ITEM & & SA & A & U & D & SD & TOTAL & REMARK \\
\hline 2 & $\begin{array}{l}\text { This would likely inflate corruption in the } \\
\text { system and lecturers not willing to publish } \\
\text { any longer }\end{array}$ & 5 & 4 & 3 & 2 & 1 & 15 & 3 \\
\cline { 3 - 9 } & & 26 & 3 & 1 & - & - & 30 & \\
$(100)$ & $(12)$ & $(3)$ & $(0)$ & $(0)$ & $(145)$ & 4.8 \\
\hline
\end{tabular}

Data from item two, table two, indicates that lecturers would likely be forced to submit to brown envelops in order to meet up with family demands or other necessities.

Research Question 3: Did the exercise prove respect for the rule of collective bargaining in industrial relations practice?

Table

\begin{tabular}{|l|l|c|c|c|c|c|c|c|}
\hline ITEM & & SA & A & U & D & SD & TOTAL & REMARK \\
\hline 3 & $\begin{array}{l}\text { Having despised the trade union, implies } \\
\text { that there was no collective bargaining } \\
\text { exercise }\end{array}$ & 5 & 4 & 3 & 2 & 1 & 15 & 3 \\
\cline { 2 - 10 } & 23 & 6 & 1 & - & - & 30 & \\
$(115)$ & $(24)$ & $(3)$ & $(0)$ & $(0)$ & $(142)$ & 4.7 \\
\hline
\end{tabular}


Data in table three also supports the claim of the papers that the exercise violated the rule of collective bargaining in industrial relations practice.

The paper then concludes and recommends that the violation of collective bargaining is still being felt in industrial relations practice in Nigeria, and that this is capable of crippling the system if it continues. The recommendation then is that a strong beaurocratic and judicial process should be advocated for by scholars.

\section{REFERENCES}

Adetoluju, T. (2013). Trade unions in Nigeria and the challenges. Internal Traditerranean Journal of Social Sciences 4 (6), pp 97-104.

Akinyanju, P. (1997) Trade Unions and Democratic Struggle in CGHR, Nigeria-A non Government Organization and Democracy, Lagos CDHR, pp 65-88.

Allwell Ome-Egeonu (2015) Introduction to Industrial Relations in Nigeria, Familia House Publishers, Rivers State.

Bernstein, A. (1999) All's not Fair in Labour Wars. Employee relations law journal, 24 (3) pp 31-53.

Davies, P. (1994) The Representation of Workers in the United Kingdom from Collective Lasse-Taire to Market Individualism. Comparative labour law, journal 15 (2). Pp 169-170.

Dunlop, T. (2009) Employees' Participation in (eds) T Redman and Wilkinson, Contemporary Human Resource Management, London, Pearson.

Edward, P. (2003) Industrial Relations Theory and Practice, Blackwell Publishers, London.

Ewekpum, G. (2010) Effective Collective Bargaining Panacea to Industrial Unrest, a Retrieved Material from Callaprica.com

Flanders, A. (1965) Industrial Relations: what is wrong with the system

Girigiri, B.A. (2002) Industrial Relations in Nigeria: Issues in Contemporary Public Sector Crisis, Port Harcourt. 